This item was submitted to Loughborough's Research Repository by the author.

Items in Figshare are protected by copyright, with all rights reserved, unless otherwise indicated.

\title{
Moderators affecting the relationship between coopetition and company performance.
}

PLEASE CITE THE PUBLISHED VERSION

https://doi.org/10.1108/JBIM-03-2018-0102

PUBLISHER

(C) Emerald

VERSION

AM (Accepted Manuscript)

\section{PUBLISHER STATEMENT}

This work is made available according to the conditions of the Creative Commons Attribution-NonCommercialNoDerivatives 4.0 International (CC BY-NC-ND 4.0) licence. Full details of this licence are available at: https://creativecommons.org/licenses/by-nc-nd/4.0/

\section{LICENCE}

CC BY-NC-ND 4.0

\section{REPOSITORY RECORD}

Crick, Jim. 2019. "Moderators Affecting the Relationship Between Coopetition and Company Performance.". figshare. https://hdl.handle.net/2134/36160. 


\title{
MODERATORS AFFECTING THE RELATIONSHIP BETWEEN COOPETITION AND COMPANY PERFORMANCE
}

\begin{abstract}
Purpose - The purpose of this paper is to examine the moderating factors that could affect the relationship between coopetition (the interplay between cooperation and competition) and company performance.

Design/methodology/approach - Under the relational view and resource-based theory, key articles surrounding coopetition were reviewed. A conceptual framework (with six research propositions) was developed to understand the nature of the relationship between coopetition and company performance.
\end{abstract}

Findings - While the coopetition - company performance relationship has been wellstudied, this link could be moderated by: the competitive business environment, organizational resources and capabilities, and trust between rivals. Further, most authors have explored the linear relationship between coopetition and company performance; however, in this paper, the non-linear (inverted U-shaped) link is also conceptualized, whereby, firms might experience "too little" and "too much" coopetition in their business strategies.

Practical implications - Management teams should engage in an "optimal-level" of coopetition by sharing resources and capabilities with rival firms, but not to the extent where they depend on such competitors. If firms rarely collaborate with their competitors, they risk not being able to achieve their performance objectives. Likewise, if businesses engage in excessive degrees of coopetition, there could be tensions between the rival companies involved. Also, practitioners should be aware of the factors that can improve or reduce their performance when they implement coopetition activities. By taking: the competitive business environment, organizational resources and capabilities, and trust between rivals into consideration, the themes of this paper should be used to help managers to maximize company performance (considered in multiple capacities).

Originality/value - This paper is used to help scholars and practitioners to understand the factors that could help or hinder the performance outcomes of coopetition activities. By appreciating the moderating roles of: the competitive business environment, organizational resources and capabilities, and trust between rivals, managers are anticipated to provide themselves with scope to alter their coopetition activities to improve their performance. This article ends with a series of managerial implications, alongside some limitations and avenues for future research.

Key words - Coopetition, company performance, moderators, strategic alliances, relational view, resource-based theory.

Classification - Conceptual paper.

\section{Introduction}

A common theme in the marketing literature is that organizational performance should be maximized through managers using their companies' own resources and 
capabilities in their business strategies (Baker, Black and Hart, 1998; Vorhies and Morgan, 2005; Morgan, 2012; Kumar, 2018). Theories, like the resource-based view, have assumed that managers should use their firms' assets to achieve their objectives and should not cooperate with their competitors (Barney, 1991; Hunt and Morgan, 1995; Morgan, Strong and McGuiness, 2003; Wernerfelt, 2014). These insights surrounding competitive rivalry have suggested that in hyper-competitive markets, inter-firm cooperation is discouraged (Kilduff, Galinsky, Gallo and Reade, 2016). However, there has been an emerging body of knowledge (such as in the businessto-business marketing literature) that has considered how some organizations have limited assets, for which the only way to achieve managers' objectives is to collaborate with competitors, so that new resources and capabilities can be accessed (including strategic alliances) (Xie and Johnston, 2004; Bello, Katsikeas and Robson, 2010; Ali and Khalid, 2017; Gnyawali and Charleton, 2018). Consequently, the notion of "coopetition" (synonymously referred to as coopetition activities) highlights the interplay between cooperation and competition, whereby, managers collaborate with their competitors to access new resources and capabilities (Kim, Kim, Pae and Yip, 2013; Yami and Nemeh, 2014; Granata, Lasch, Le Roy and Dana, 2018).

Bengtsson and Kock (1999) were among the first scholars to explore coopetition in the business-to-business marketing literature. These authors used a network approach to outline the benefits of managers cooperating with rival organizations. They argued that by sharing resources and capabilities with competitors, managers are equipped with new opportunities to strengthen their value chains. Prior to Bengtsson and Kock's (1999) study, other authors had examined inter-firm cooperative strategies (including coopetition) (e.g., Brandenburger and Nalebuff, 1996; Dowling, Roering, Carlin and Wisnieski, 1996; Rosenfeld, 1996), but their paper began the evolution of the 
coopetition literature (see Ballantyne, 2004; Tidstrom, 2009; Bengtsson and Kock, 2014; Iyer, 2014; Akpinar and Vincze, 2016; Leite, Pahlberg and Aberg, 2018; Mathias, Huyghe, Frid and Galloway, 2018). Interestingly, Bengtsson and Kock (1999) highlighted how coopetition activities involve paradoxical relationships between cooperation and competition. In their later work, these authors extended the limited theory surrounding coopetition, as instead of examining it as a firm-level mind-set (as per Brandenburger and Nalebuff, 1996), they conceptualized the interplay between cooperation and competition as a behavioral process (see Bengtsson and Kock, 2000).

They formally defined coopetition as "a dynamic and paradoxical relationship, which arises when two companies cooperate in some areas (such as strategic alliances), but simultaneously compete in other areas" (Bengtsson and Kock, 2000, p. 411). To emphasize an important point, coopetition has been well-studied in the business-tobusiness marketing literature, with a surge of papers across the 2000s and 2010 s (Gnyawali and Park, 2009; Ritala, 2012; Velu, 2016; Hannah and Eisenhardt, 2018). For instance, scholars have explored: coopetition within corporations (e.g., Luo, Slotegraaf and Pan, 2006), international forms of coopetition (e.g., Luo, 2007), coopetition with supply chain channels (vertical coopetition), (e.g., Tidstrom, 2014), as well as coopetition across a range of empirical contexts (Czakon and Czernek, 2016; Gnyawali and Charleton, 2018). Hence, the definition of coopetition has been revised since Bengtsson and Kock's (2000) study. Specifically, coopetition is "a paradoxical relationship between two or more actors, regardless of whether they are in horizontal or vertical relationships, simultaneously involved in cooperative and competitive interactions" (Bengtsson and Kock, 2014, p. 180). 
Coopetition is comprised of resource and capability-sharing activities between two or more competitors (Dahl, 2014; Peters and Pressey, 2016; Hannah and Eisenhardt, 2018). Resource-sharing activities concern managers disseminating assets, such as equipment with their competitors, whereas, capability-sharing activities are when managers trade assets (like knowledge and experience) with their rivals (Tidstrom, 2009; Felzensztein, Gimmon and Aqueveque, 2012; Crick, 2018a). Resource and capability-sharing activities are employed to provide managers with opportunities (e.g., new markets) that they would not be able to access if they competed under an individualistic business model (where coopetition does not exist) (Rao and Perry, 2002; Bengtsson and Johansson, 2014; Park, Srivastava and Gnyawali, 2014). Coopetition has primarily been investigated from the perspective of managers in smaller organizations (with limited resources and capabilities) to highlight how management teams might require competitors' assistance to achieve their objectives (Tuusjarvi and Moller, 2009; Rusko, 2011; Ritala and Hurmelinna-Laukkanen, 2013; Bengtsson and Raza-Ullah, 2016). Although some research has been conducted on how coopetition can be implemented by large corporations (e.g., Luo, 2005; Gnyawali and Park, 2011; Arslan, 2018), coopetition has been extensively-explored as a business strategy adopted by small firms.

Coopetition activities have been related to various assessments of company performance to demonstrate that by collaborating with competitors, smaller businesses are likely to perform better than if they did not utilize their competitors' resources and capabilities (Eriksson, 2008; Dahl, 2014; Peters and Pressey, 2016; Velu, 2016; Hoffmann, Lavie, Reuer and Shiplov, 2018). While the coopetition company performance relationship has been well-studied, a major research problem is that this relationship has been evaluated as being non-contingent - with certain 
exceptions (e.g., Ang, 2008; Ritala, 2012; Bouncken and Kraus, 2013; Wu, 2014). It is critical to study whether there are moderating factors (or contingencies) that could help or hinder the performance outcomes of coopetition activities. Thus, the objective of this paper is to examine the contingencies that could affect the relationship between coopetition and company performance. By investigating such contingencies, recommendations can be made to scholars and practitioners about the conditions that collaborating with competitors should (and should not) drive company performance (conceptualized in multiple capacities).

Although there is likely to be a positive relationship between coopetition (or similar cooperative business strategies) and company performance (Gnyawali and Park, 2009; Iyer, 2014; Crick and Crick, 2016), it is more important to understand how managers can manipulate their coopetition activities to maximize company performance. Further, in this article, under the relational view and resource-based theory (the resource-based view), the linear and non-linear links between coopetition and company performance are conceptualized. By exploring the non-linear relationship between coopetition and company performance, this study contributes to a recent body of literature that has examined some of the negative aspects of coopetition (including inter-firm tensions) (Kim et al., 2013; Raza-Ullah, Bengtsson and Kock, 2014; Czakon and Czernek, 2016; Fernandez and Chiambaretto, 2016). Henceforth, this paper is divided as follows. First, a review of the coopetition literature is undertaken. Second, the linear and non-linear relationships between coopetition and company performance are examined. Third, several factors are explored as being moderators in the link between coopetition and company performance. Fourth, a series of managerial implications are highlighted. Fifth, some limitations and avenues for future research are described. Sixth, the paper is concluded. 


\section{Framing literature}

Theories used to explain cooperative business strategies

The resource-based view of the firm examines how organizations can obtain sustainable competitive advantages through their resources and capabilities (Tzokas and Saren, 2004; O'Cass, Ngo and Siahtiri, 2015; Girod and Whittington, 2017). The resource-based view was originally-conceptualized as being an individualistic theory, involving managers using their firms' assets in their business strategies (Wernerfelt, 1984; Barney, 1991; Hunt and Morgan, 1995). However, it has been extended to incorporate a cooperative dimension, whereby, authors, such as Dyer and Singh (1998, p. 660) highlighted that "a firm's critical resources may span firm boundaries and may be imbedded in inter-firm resources and routines" (the relational view). Consequently, the resource-based view has accounted for cooperation between organizations, such as strategic alliances (Glynn, Motion and Brodie, 2007). One subset of the resource-based view is the dynamic capabilities perspective. Dynamic capabilities are defined as "the firm's ability to: integrate, build, and reconfigure internal and external competences to address rapidly-changing (dynamic) environments" (Teece, Pisano and Shuen, 1997, p. 524). Dynamic capabilities (comprised of: sensing, seizing, and transforming-based intangible assets) allow companies to obtain sustainable competitive advantages through being able to adapt and reconfigure in competitive business environments (Winter, 2003; Zahra, Sapienza and Davidsson, 2006; Teece, 2018). Some firms use coopetition to obtain sustainable competitive advantages (as a dynamic capability), making this sub-set of resource-based theory highly-applicable to cooperative business strategies (Crick, 2015). 
The relational view examines the networks and dyads that companies utilize to explain relational rents (Gronroos, 1997; Coviello and Brodie, 2001; Ylimaki and Vesalainen, 2015). Relational rents are a "a super-normal profit, jointly generated in an exchange relationship that cannot be generated by either firm in isolation and can only be created through the joint idiosyncratic contributions of the specific alliance partners" (Dyer and Singh, 1998, p. 662). There are four sources of relational rents, namely: relationspecific assets (the duration of safeguards and the volume of inter-firm transactions), knowledge-sharing routines (partner-specific absorptive capacity and incentives to encourage transparency and discouraging free-riding), complementary resources/capabilities (an ability to identify and evaluate potential complementarities and the role of organizational complementarities to access benefits of strategic resource complementarity), and effective governance (an ability to employ selfenforcement, rather than third-party self-enforcement governance mechanisms and an ability to employ informal self-enforcement governance mechanisms) (Mesquita, Anand and Brush, 2008).

\section{Assessments of company performance}

Resource-based theory, including the dynamic capabilities perspective, typically uses sustainable competitive advantages are a performance outcome (Barney, 1991; Tzokas and Saren, 2004; Vorhies and Morgan, 2005; Morgan, 2012; Crick and Crick, 2014; Katsikeas, Morgan, Leonidou and Hult, 2016; Girod and Whittington, 2017). Sustainable competitive advantages are where organizations have out-performed their key competitors within a certain market, over an extended period, while withstanding the forces of the competitive business environment (e.g., technological turbulence) (Bharadwaj, Varadarajan and Fahy, 1993; Zahra et al., 2006; Newbert, 2007; Olson, Slater, Hult and Olson, 2018). Under the relational view, company 
performance has been assessed through collaborative advantages, namely, the: duration, objectives, and financial performance of collaborative business strategies (Kanter, 1994; Ploetner and Ehret, 2006). Collaborative advantages also evaluate how companies need to find mutually-beneficial performance outcomes when collaborating with their network members (see Dyer, Singh and Hesterly, 2018), something that equally applies to coopetition activities (Lavie, 2006; Rusko, 2011; Ritala, 2012; Crick, 2018a). Consequently, in this article, company performance is conceptualized under the outcomes set by the relational view and resource-based theory.

\section{Different forms of coopetition}

Coopetition activities can occur in three capacities; that is: "cooperation-dominated relationships" are when "relationships consist of more cooperation than competition", "equal relationships, are where cooperation and competition are equally-distributed", and "competition-dominated relationships", which are when "relationships consist of more competition than cooperation" (Bengtsson and Kock, 2000, p. 416). Therefore, coopetition challenges some of the hyper-competitive assumptions pertaining to early forms of resource-based theory (Wernerfelt, 1984; Barney, 1991; Hunt and Morgan, 1995) by highlighting that managers should collaborate with their competitors to acquire new resources and capabilities (Combs and Ketchen Jr., 1999; Ballantyne, 2004; Gnyawali and Park, 2011). Managers have scope to decide on the degree to which they engage in coopetition, depending on the extent to which they are cooperative or competitive with their rivals (Park et al., 2014; Peters and Pressey, 2016; Leite et al., 2018). Yet, coopetition is still a competitive (and cooperative) business strategy; hence, even in the most collaborative forms of coopetition, there will always be a certain magnitude of competitiveness between the firms involved (lyer, 2014; Hannah and Eisenhardt, 2018). 
Ranganathan, Ghosh and Rosenkopf (2018) examined a sample of corporations competing in the computing industry. They suggested that firms are more likely to engage in coopetition is they have a high product-market overlap with the entities involved in such activities. A product-market overlap is the extent to which companies compete for comparable customer segments and offer similar goods and/or services (Luo, 2007). That is, while coopetition is underpinned by cooperative and competitive dimensions (following Bengtsson and Kock, 2000; Gnyawali and Park, 2009; Gnyawali and Charleton, 2018), it is still a business strategy comprised of rival firms, with managers that seek to fulfil their own performance objectives (Hoffmann et al., 2018). Indeed, coopetition can yield performance outcomes that benefit all businesses involved (e.g., joint value creation for customers); yet, managers are well-served if they remain in competition with their coopetition partners (Arslan, 2018). Henceforth, resource and capability-sharing activities can drive company performance (Crick, 2018a), but there will be a point when inter-firm cooperativeness ends and the interfirm rivalry resumes (following Ang, 2008; Ritala, 2012; Bouncken and Kraus, 2013).

Coopetition is likely to occur when two or more companies realize that organizational performance is more likely to be obtained when they have access to a greater pool of resources and capabilities, which can be yielded through collaborating with their competitors (Rusko, 2011; Kim et al., 2013; Bengtsson and Kock, 2014; Hoffmann et al., 2018). Following an earlier point, coopetition is a cooperative (and competitive) business strategy, meaning that such activities must yield mutually-beneficial performance outcomes (e.g., improved opportunities in firms' markets and joint value creation for customers) (Bengtsson and Kock, 2000; Ballantyne, 2004; Arslan, 2018). Indeed, certain authors have noted that if companies manage a coopetition-oriented mind-set (beliefs focused on the importance and value of cooperating with 
competitors), they are likely to engage in coopetition activities (Gnyawali and Park, 2011; Crick, 2018a). That is, if managers believe that sharing resources and capabilities with their competitors is likely to improve company performance, their firmlevel behaviors are likely to be manifestations of their mind-set (coopetition activities) (Brandenburger and Nalebuff, 1996). Hence, coopetition is likely to occur with the precursor of organizations being prepared to share assets with their rivals (Mathias et al., 2018).

\section{Empirical contexts for studying coopetition}

When investigating coopetition, it is important for scholars to select an empirical context that is highly-cooperative and highly-competitive (Crick, 2018b). That is, coopetition is the interplay between cooperation and competition, whereby, organizations collaborate with their competitors to improve their performance (Rosenfeld, 1996; Ritala, 2012; Bengtsson and Raza-Ullah, 2016). It can be difficult for academics to locate an empirical setting that hosts high-degrees of cooperativeness and competitiveness ${ }^{1}$. A high-degree of cooperativeness involves firms sharing resources and capabilities with rival firms in formal or informal capacities (Lavie, 2006; Dahl, 2014; Hannah and Eisenhardt, 2018). A high-degree of competitiveness entails businesses being in fierce rivalry for similar markets (Porter, 1985; Baker et al., 1988; Girod and Whittington, 2017; Gnyawali and Charleton, 2018). For instance, some authors have investigated coopetition using data from high-tech

\footnotetext{
${ }^{1}$ Scholars should select a highly-cooperative and highly-competitive empirical context to investigate coopetition because they can use such a setting to understand how cooperative and competitive forces integrate (Crick, 2018b). Without such industry dynamics, it could be difficult to assess the antecedents and consequences of coopetition activities, especially with quantitative data, where there may be little variance. The author expresses gratitude to an anonymous reviewer for making this point.
} 
corporations (e.g., Dowling et al., 1996; Gnyawali and Park, 2011; Wu, 2014). More frequently, scholars have examined agricultural markets, in which businesses compete within regional clusters (including alcohol producers), which presents ample scope for cooperative business strategies (see Rusko, 2011; Felzensztein, Gimmon and Deans, 2018; Granata et al., 2018; Mathias et al., 2018).

\section{Drivers of coopetition}

A body of knowledge surrounds the drivers (or antecedents) of coopetition activities (Hoffmann et al., 2018). Following the previous section, the most common driver of coopetition has been the firm-level and industry-level coopetition-oriented mind-sets that motivate managers to share resources and capabilities with their competitors (Gnyawali and Park, 2011; Crick, 2018a; Mathias et al., 2018). That is, prior theory has indicated that if managers believe that collaborating with their competitors is an important activity (i.e., something that has a positive impact on company performance), then, such individuals are likely to engage in behavioral forms of coopetition (resource and capability-sharing activities) (Brandenburger and Nalebuff, 1996). Further, other authors have stressed that managers must have access to competitors' resources and capabilities for coopetition to exist (Ganesan, Malter and Rindfleisch, 2005; Felzensztein et al., 2012; Granata et al., 2018). While the drivers of coopetition are important to increasing marketing scholars' understanding of how such activities can be best-managed (Gnyawali and Charleton, 2018), this investigation highlights the nature of the coopetition - company performance relationship.

\section{Coopetition in the business-to-business marketing literature}

As mentioned earlier, coopetition originated from the business-to-business marketing literature, in which journals, such as: the Journal of Business \& Industrial Marketing, 
Industrial Marketing Management, and the Journal of Business-to-Business Marketing have published a range of articles examining the antecedents and consequences of firms collaborating with their competitors (Bengtsson and Kock, 1999; Eriksson, 2008; Kim et al., 2013; Bengtsson and Raza-Ullah, 2016; Fernandez and Chiambaretto, 2016). Although scholars have contributed to the business-to-business marketing literature with coopetition-based studies, there are still certain research gaps. Indeed, in 2014, a special issue of Industrial Marketing Management was published on the interplay between cooperation and competition (edited by Bengtsson and Kock, 2014), followed by a special section in the same journal on a similar topic in 2016 (led by Bengtsson, Kock, Lundgren-Henriksson and Nasholm, 2016). In Bengtsson and Kock's (2014) paper, the authors proposed that future coopetition research should examine issues, like the tensions that might exist when two or more companies share resources and capabilities, as well the dynamics and performance outcomes of the interplay between cooperation and competition.

Conversely, this article responds to Bengtsson and Kock's (2014) call for research by examining the nature of the relationship between coopetition and company performance, including certain tensions (trust between rivals) that could affect this link. Specifically, while marketing academics have incrementally strengthened the coopetition literature with new conceptualizations and empirical evidence pertaining to the construct (e.g., Luo et al., 2006; Dahl, 2014; Akpinar and Vincze, 2016; Velu, 2016; Chou and Zolkiewski, 2018), there are still prominent research gaps. By focusing on the linear and non-linear (inverted U-shaped) relationships between coopetition and company performance, as well as some key moderating factors, this paper strengthens the coopetition literature with improved conceptualizations into how firms can best-manage the interplay between cooperation and competition. Hence, by 
investigating the nature of the relationship between coopetition and company performance, scholars and practitioners can learn about the conditions when coopetition is most (and least) likely to improve company performance (following Ang, 2008; Ritala, 2012; Bouncken and Kraus, 2013).

In the special section of Industrial Marketing Management in 2016, certain papers focused on the factors that can help or hinder the companies form maximizing the performance outcomes of collaborating with their competitors (Bengtsson et al., 2016). Key examples include the role of the competitive business environment (Chiambaretto and Fernandez, 2016) and the degree of trust between rival entities (Czakon and Czernek, 2016). More recently, the Strategic Management Journal published a special issue on the interplay between cooperation and competition (edited by Hoffmann et al., 2018). Just like the special section and special issue of Industrial Marketing Management, the papers focused on the ways to maximize the performance outcomes of coopetition activities (e.g., Arslan, 2018; Hannah and Eisenhardt, 2018; Mathias et al., 2018; Ranganathan et al., 2018). Such research provides extra reasoning to suggest that additional conceptualizations are needed to explore the nature of the relationship between coopetition activities and company performance. The relationship between coopetition and company performance follows in the next section.

\section{Coopetition and company performance}

Due to resource and capability-sharing activities helping mangers to access new opportunities, coopetition is highly-likely to drive different company performance outcomes (Combs and Ketchen Jr., 1999; Ritala, 2012; Yami and Nemeh, 2014). For example, Crick (2015) found that coopetition activities can drive small firms to survive 
within their market by having access to new resources and capabilities. Specifically, some smaller organizations might have so few resources and capabilities, that managers cannot invest their firms' assets towards the strategies that they need to run their business (Hunt and Derozier, 2004; O'Cass et al., 2015). Hence, resource and capability-sharing activities provide managers in smaller companies with the opportunities to access the assets that are necessary to compete within their markets (Bengtsson and Johansson, 2014; Granata et al., 2018). Additionally, Crick (2018a) found that if individual organizations (that customers are unfamiliar with) were to promote their goods and services as stand-alone brands, sales would be low; however, if a group of competing brands were to collaborate and run promotional events (like trade shows), customers would be more interested, which could potentially improve the sales of all the organizations involved.

Thus, coopetition should improve the performance of all firms engaged in such activities (Felzensztein et al., 2012; Velu, 2016; Chou and Zolkiewski, 2018). The mutual performance outcomes of coopetition link with collaborative advantages (under the relational view) (Kanter, 1994; Ploetner and Ehret, 2006; Butler and Batt, 2014; Dyer et al., 2018). Despite coopetition being primarily studied from the perspective of managers in smaller companies (Gnyawali and Park, 2009; Ritala and HurmelinnaLaukkanen, 2013), coopetition can also be used to help larger firms, such as in largescale and global strategic alliances (Xie and Johnston, 2004; Lavie, 2006; Ali and Khalid, 2017). Managers in larger firms might still need to collaborate with their competitors, due to reasons, like promoting their brand internationally (Bello et al., 2010; Arslan, 2018). Even larger organizations could struggle to achieve certain objectives, such as targeting international markets, something that could be eased through collaborating with competitors (Luo, 2007). As per resource-based theory, due 
to the size and scope of larger organizations, managers can combine the benefits of coopetition (e.g., new assets from rivals), with their existing assets, to obtain sustainable competitive advantages, something that smaller firms cannot obtain (see Gnyawali and Park, 2011). However, coopetition should be employed to provide managers with new assets and viewpoints on their competitive business environment that would not exist under an individualistic business model, that is, without collaborating with competitors (Eriksson, 2008; Kim et al., 2013; Ritala, Golnam and Wegmann, 2014; Ranganathan et al., 2018).

Small businesses collaborate with their competitors through the sharing of resources and capabilities to perform better than if they operated on an individualistic-level (Bengtsson and Kock, 1999; Ritala and Hurmelinna-Laukkanen, 2013; Dahl, 2014; Granata et al., 2018). The managers of small firms are likely to have informal networks with their competitors, whereby, such entities might have friendly relationships with rival firms, allowing them to access new resources and capabilities (Felzensztein et al., 2018). Owing to their size and scope, for larger firms, coopetition is likely to be more formal, with contracts and legal obligations underpinning the alliances they form with their rivals (Luo, 2005; Gnyawali and Park, 2011). Coopetition is intended to help small and large companies to improve their performance in ways that would not be possible without competitors' resources and capabilities (Bengtsson and Kock, 2000; Ritala, 2012; Crick, 2018a). It appears that as firms engage in coopetition activities, it becomes more likely that they improve their performance (Bengtsson and Raza-Ullah, 2016). Such performance outcomes could include collaborative advantages (as per the relational view) and sustainable competitive advantages (according to resourcebased theory) (Barney, 1991; Gronroos, 1997; Dyer and Singh, 1998; Dyer et al., 2018). Under these findings, it is anticipated that: 
P1. Coopetition has a linear (positive) relationship with company performance. The more that companies collaborate with their competitors, there is a greater chance of improving their performance.

Managers might be provided with new resources and capabilities from their competitors (Rusko, 2011; Mathias et al., 2018), but they need to be careful about the tensions that could exist between such rival firms. Tensions in coopetition relationships include: decreasing trust between competitors, inter-firm conflict and/or power imbalances, and poor communication (Bengtsson and Kock, 2014; Raza-Ullah et al., 2014; Tidstrom, 2014; Chiambaretto and Fernandez, 2016). Park et al. (2014) discussed how coopetition activities, when affected by market competition, have an inverted U-shaped relationship with innovation (as an assessment of performance). Managers may find that coopetition activities lead to improvements in various forms of company performance (e.g., collaborative advantages or sustainable competitive advantages), but a diminishing-returns effect could be caused, in which "too many" resource and capability-sharing activities could harm such performance outcomes (Bouncken and Kraus, 2013; Ritala and Hurmelinna-Laukkanen, 2013; Hoffmann et al., 2018). Indeed, "too little" could exist when managers do not acquire enough resources and capabilities from rival firms (Bengtsson and Kock, 1999; Ritala, 2012; Leite et al., 2018). Consequently, managers are faced with the difficult task of reaching an "optimal-level" of coopetition (Park et al., 2014). Henceforth, it is proposed that:

$P 2$. Coopetition has a non-linear (inverted U-shaped) relationship with company performance. With "too little" coopetition, firms limit the opportunities in their markets, whereas, "too much" coopetition can lead to certain negative consequences. 
It is accepted that the literature underpinning P1 and P2 highlights that the coopetition - company performance relationship could be linear or non-linear (inverted U-shaped). Specifically, prior studies have indicated both types of linkages between collaborating with competitors and company performance (e.g., Bengtsson and Kock, 1999; Ang, 2008; Ritala, 2012; Bouncken and Kraus, 2013; Bengtsson and Johansson, 2014; Velu, 2016; Gnyawali and Charleton, 2018). Thus, in this current paper, P1 and P2 signify these two schools-of-thought exhibited by business-to-business marketing scholars $^{2}$. Some contingencies (moderating factors) affecting the coopetition company performance relationship follow in the next section.

\section{Contingencies in the relationship between coopetition and company performance}

\section{Competitive business environment}

The original conceptualizations of the resource-based view were driven by rigid assumptions about firm-level competitiveness, surrounding the principles of microeconomics (Wernerfelt, 1984; Barney, 1991; Hunt and Morgan, 1995). More recently, the resource-based view has expanded to account for issues associated with the competitive business environment (Newbert, 2007; Kunc and Morecroft, 2010; Teece,

\footnotetext{
${ }^{2}$ It is acknowledged that many business strategies and firm-level activities can have a positive link with company performance, including market-oriented behaviors or innovativeness (Jaworski and Kohli, 1993; Carbonell and Escudero, 2010; Kumar, Jones, Venkatesan and Leone, 2011; Ozkaya, Droge, Hult, Calantone and Ozkaya, 2015; Crick and Crick, 2018). However, in this article, coopetition activities are explored as being a key driver of company performance (Dahl, 2014; Bengtsson and Raza-Ullah, 2016; Hannah and Eisenhardt, 2018). Indeed, as stressed throughout this article, the nature of the relationship between coopetition and company performance is under-researched in certain respects (Bengtsson and Kock, 2014; Bengtsson et al., 2016; Hoffmann et al., 2018). Henceforth, this investigation contributes to this underresearched strand of literature by exploring how coopetition activities drive company performance. The author thanks an anonymous reviewer for suggesting this point.
} 
2018). The competitive business environment is the external forces that affect how organizations compete within their markets (following Slater and Narver, 1994; Piercy, 2010; Tzempelikos and Kooli, 2018). For instance, Girod and Whittington (2017) highlighted that dynamic capabilities are more likely to improve company performance in rapidly-changing markets. Regarding coopetition, Ritala (2012) found that in situations of high market uncertainty (when the wants and needs of customers are difficult to predict), collaborating with competitors is more likely to lead to improved market and innovation performance, due to managers sharing costs with their competitors. Ritala (2012) also found that coopetition activities are less likely to drive innovation and market performance in sectors where competitors are relatively strong. Further, Ang (2008) discovered that competitive intensity (the degree to which firms face fierce rivalry in their markets) and technological turbulence (the extent to which technology changes within a market) weaken the relationship between coopetition activities and company performance.

The competitive business environment is not a prominent factor within the relational view, as this perspective focuses on the relationships between companies that are used to obtain relational rents and obtain collaborative advantages (Coviello and Brodie, 2001; Ploetner and Ehret, 2006; Butler and Batt, 2014; Ylimaki and Vesalainen, 2015). Interestingly, the relational view is based upon the cooperative relationships firms have with their competitors (Gronroos, 1997; Dyer and Singh, 1998; Lavie, 2006; Dyer et al., 2018); yet, the ways that collaborative networks and dyads fit into the competitive business environment are not part of this theoretical viewpoint. Instead, the competitive business environment is better-suited to the additions made to the resource-based view (see Barney, 2001; Priem and Butler, 2001), which have transferred to more recent studies that have been underpinned by resource-based 
theory (Hoskisson, Gambeta, Green and Li, 2018; Nason and Wiklund, 2018). It is of interest to explore whether the competitive business environment has any impact on the performance outcomes of coopetition activities (following Chiambaretto and Fernandez, 2016). Such performance outcomes could be collaborative advantages (as per the relational view) or sustainable competitive advantages (guided by resource-based theory) (Kanter, 1994; Dyer and Singh, 1998; Vorhies and Morgan, 2005; Zahra et al., 2006; Wernerfelt, 2014; Katsikeas et al., 2016).

Often, as markets become more competitive, organizations must develop more innovative business strategies to generate demand from their customers (Carbonell and Escudero, 2010; Crick, Chaudhry and Crick, 2016; Teece, 2018). If new entrants develop a strong presence within their markets (e.g., become better-known by customers), existing firms might struggle to retain their customers and attract new ones (Porter, 1985). If markets are competitive, there is a reasonable chance that there will be a high-level of distrust between such companies (Felzensztein et al., 2012; Czakon and Czernek, 2016). If managers distrust their competitors (especially in competitive markets), they have little incentive to cooperate with rival firms, due to the risk of losing valuable resources and capabilities through such collaborative business strategies (Ritala and Hurmelinna-Laukkanen, 2013; Raza-Ullah et al., 2014; Tidstrom, 2014). Additionally, coopetition is more likely to be successful (in terms of a positive link with company performance) when there are friendships and informal social relationships between competing organizations (Crick and Crick, 2016; Peters and Pressey, 2016). That said, if trust is non-existent (due to the competitive business environment), it could be extremely difficult for managers to be motivated to engage in coopetition activities (Tidstrom, 2009; Hoffmann et al., 2018). Therefore, one argument is that: 
P3. The competitive business environment negatively moderates the relationship between coopetition and company performance. As markets become more competitive, there can be higher-levels of distrust between rival entities, affecting the performance outcomes.

The competitive business environment could have different performance consequences, when coupled with coopetition activities. Specifically, as markets become more competitive, managers could struggle to develop business strategies that will yield sustainable competitive advantages (or collaborative advantages), due to there being increased rivalry for their same customer segments (as per Ang, 2008; Ritala, 2012; Bouncken and Kraus, 2013; Crick et al., 2016). However, an alternative viewpoint to the above-described research proposition, is that as industry rivalry becomes fiercer, a greater number of rivals could mean that management teams have more opportunities to engage in coopetition (Ganesan et al., 2005; Felzensztein et al., 2018; Mathias et al., 2018). Management teams are more likely to develop performance-driving forms of coopetition if competitors' resources and capabilities can be accessed (Felzensztein et al., 2012; Granata et al., 2018). Furthermore, coopetition activities are effective when organizations are within a close geographic proximity, owing to improving inter-firm relationships (Bengtsson and Kock, 1999; Geldes, Heredia, Felzensztein and Mora, 2017). With a greater number of rivals, an increased degree of competitiveness could also facilitate stronger forms of coopetition activities, in which managers can yield higher-levels of performance than in markets where fewer rivals compete (Crick, 2018a). Therefore, it follows that:

P4. The competitive business environment positively moderates the relationship between coopetition and company performance. As markets host 
more organizations, there can be more scope for companies to collaborate with their competitors.

\section{Organizational resources and capabilities}

Organizational resources and capabilities are the volume of tangible and intangible assets that companies possess (Wernerfelt, 1984; Barney, 1991; Hunt and Morgan, 1995). Under the resource-based view, smaller organizations can obtain sustainable competitive advantages, but to a lesser-extent through their resources and capabilities, as they should exploit factors, like their owner-managers' heritage, to develop a strong customer value provision (Westhead, Wright and Ucbasaran, 2001; Morgan, 2012; O'Cass et al., 2015; Nason and Wiklund, 2018). Larger companies have more scope to obtain sustainable competitive advantages, as their management teams have a greater volume of resources and capabilities than smaller firms that cannot afford to lose such assets (Barney, Ketchen Jr. and Wright, 2011; Wernerfelt, 2014; Hoskisson et al., 2018). Thus, it is of interest to explore whether organizational resources and capabilities moderate the coopetition - company performance relationship (following Arslan, 2018; Ranganathan et al., 2018). For example, Crick (2018a) found that larger firms can combine their existing assets with the benefits they have obtained from collaborating with their competitors to develop their performance in ways that smaller rivals cannot imitate. Crick (2018a) discovered that these larger companies were able to collaborate with their rivals to the extent where they obtain a sustainable competitive advantage, such as developing superior products and services that could not be imitated by smaller firms.

Gnyawali and Park (2011) focused on "coopetition between giants", using empirical and archival data from Samsung Electronics and the Sony Corporation. Instead of 
examining the performance outcomes of coopetition, Gnyawali and Park (2011, p. 658) highlighted that key consequences of coopetition activities include: "value creation and appropriation, industry technological development and standards, and industry competitive dynamics." Using an in-depth case study (through multiple sources of empirical and archival data), they found that organizational resources and capabilities affect the relationship between coopetition activities and the abovementioned outcomes. Gnyawali and Park (2011, p. 650) found that "coopetition capabilities of firms play an important role in enhancing common benefits, as well as in gaining a proportionately larger share of the benefits." That is, these authors proposed that "coopetition capabilities" (comprised of: a coopetition mind-set, coopetition experience, and organizational resources and capabilities) moderate the link between the dynamics of coopetition between giants and the outcomes of coopetition between giants. Therefore, there could be a positive association between organizational resources and capabilities (when coupled with coopetition activities) and company performance (Luo, 2005; Tuusjarvi and Moller, 2009; Peters and Pressey, 2016; Arslan, 2018).

Under resource-based theory (including the dynamic capabilities perspective), organizational resources and capabilities are intended to drive sustainable competitive advantages (Hunt and Morgan, 1995; Priem and Butler, 2001; Vorhies and Morgan, 2005; Kunc and Morecroft, 2010; Girod and Whittington, 2017; Nason and Wiklund, 2018). Therefore, following the resource-based view, management teams should aim to acquire as many resources and capabilities within their business strategies to outperform their competitors (Barney, 2001; Winter, 2003; Hunt and Derozier, 2004; Zahra et al., 2006; Crick and Crick, 2015; Teece, 2018). The relational view highlights the importance of organizational resources and capabilities, but also, stresses that 
companies need to access the correct assets from their network members, such as the ones that are most likely to improve company performance (collaborative advantages) (Gronroos, 1997; Dyer and Singh, 1998; Lavie, 2006). The relational view outlines that the relationships between organizations need to be trustworthy (Coviello and Brodie, 2001; Ploetner and Ehret, 2006; Ylimaki and Vesalainen, 2015). Hence, organizational resources and capabilities can improve the performance outcomes of coopetition (Combs and Ketchen Jr., 1999; Rusko, 2011; Crick, 2018a), but the quality of the relationships between the firms sharing such assets is also important (Dyer et al., 2018). Under these conditions, it is expected that:

P5. Organizational resources and capabilities positively moderate the relationship between coopetition and company performance. As firms obtain more assets from their competitors, they can use them to improve their performance across certain business strategies.

\section{Trust between rivals}

As described earlier, when the resource-based view was incorporated into the broader management literature, it involved managers using their firms' resources and capabilities to obtain sustainable competitive advantages (Wernerfelt, 1984; Barney, 1991; Hunt and Morgan, 1995). However, due to extensions made to resource-based theory surrounding cooperative business strategies and the relational view (e.g., Dyer and Singh, 1998), the quality of inter-firm relationships is vital to this element of the perspective (Gronroos, 1997; Lavie, 2006; Butler and Batt, 2014; Dyer et al., 2018). That is, if two or more entities share resources and capabilities, the degree of trust between such management teams could influence the extent to which coopetition positively drives company performance (Kim et al., 2013; Tidstrom, 2014; Bengtsson 
and Raza-Ullah, 2016). Further, when working with rival firms, managers must share a certain vision that cooperating with their competitors is likely to lead to mutuallybeneficial outcomes, such as improvements in their performance (Eriksson, 2008; Bengtsson and Kock, 2014; Mathias et al., 2018). If managers do not share this mindset, trust may not exist within such inter-firm relationships (Park et al., 2014; Granata et al., 2018). As such, it is important to consider whether trust between rivals moderates the coopetition - company performance relationship.

Trust between rivals is the extent to which the competitors engaging in coopetition are assured that there is honesty within such activities (following Tidstrom, 2009; Bengtsson et al., 2016; Czakon and Czernek, 2016). The relational view considers the trust between partners engaging in collaborative business strategies (Coviello and Brodie, 2001; Ylimaki and Vesalainen, 2015). That is, so that management teams can obtain relational rents, the relational view considers factors, such as: the quality of inter-firm relationships, partner-specific transactions, self-enforcement governance, and the potential complementarities of the governance of organizational resources and capabilities (Mesquita et al., 2008). Consequently, managers should be aware that when they engage in coopetition activities, they need to share an appropriate volume of resources and capabilities, as well as sharing such assets with competitors that are trustworthy (Hoffman et al., 2018). There is a high-degree of uncertainty surrounding such cooperative business strategies - regarding the tensions that might arise from collaborating with competitors (Brandenburger and Nalebuff, 1996; Ritala and Hurmelinna-Laukkanen, 2013). Henceforth, management teams should do everything within their power to ensure that they are sharing resources and capabilities with competing organizations that can be trusted - with a low chance of inter-firm tensions (Crick, 2015). 
Collaborating with competitors is a risky strategy for some businesses, as managers face the possibility that their competitors could steal or imitate their resources and capabilities (Park et al., 2014). On a smaller-scale, Crick (2018a) highlighted that when sharing resources and capabilities, some competitors may not be careful with such assets (e.g., firms might damage them), which could create tensions and financial consequences between two or more competitors. On a larger-scale, Ritala and Hurmelinna-Laukkanen (2013) suggested that if managers openly share their assets with their competitors, they risk losing intellectual property, which ultimately, could lessen performance. Additionally, multiple authors have researched some of the negative issues associated with coopetition, in which inter-firm tensions have been investigated as a potential factor that could limit the performance outcomes of coopetition activities (see Raza-Ullah et al., 2014; Tidstrom, 2014). Moreover, studies examining negative aspects of coopetition have suggested that "too little" or "too much" coopetition could be negative for performance (Ritala, 2012; Bouncken and Kraus, 2013; Ritala et al., 2014; Gnyawali and Charleton, 2018). Hence, it was recommended earlier that companies should engage in an "optimal-level" of coopetition (Park et al., 2014).

When engaging in coopetition activities, managers need to be aware of the extent that they can trust their counter-parts in competing firms (Tidstrom, 2009). If managers trust their competitors, they might be more likely to engage in resource and capabilitysharing activities to their full-extent, and in turn, improve company performance (Kim et al., 2013; Hoffmann et al., 2018). Yet, managers must appreciate that coopetition is still a competitive (and cooperative) business strategy, meaning that even in the most cooperative forms of coopetition, there will be a point that cooperativeness ends and competitiveness resumes (Ballantyne, 2004; lyer, 2014; Peters and Pressey, 2016; 
Arslan, 2018). If managers do not trust their competitors, they will probably feel uncomfortable with sharing resources and capabilities, which may limit the performance outcomes of such activities (Crick and Crick, 2016; Geldes et al., 2017). It is proposed that as the mutual trust between the firms engaging in coopetition activities increases, there is likely to be a positive effect on company performance (following Luo et al., 2006; Czakon and Czernek, 2016). This is important, as the quality of the relationships that companies have with their network members could drive performance (especially under the relational view) (Gronroos, 1997; Dyer and Singh, 1998; Mesquita et al., 2008; Butler and Batt, 2014; Dyer et al., 2018). As such, it is anticipated that:

P6. The trust between rivals positively moderates the relationship between coopetition and company performance. If businesses have trustworthy networks with rival firms, such organizations will be more likely to engage in performance-driving forms of coopetition.

This review of the coopetition literature highlights that although a direct relationship between coopetition and company performance might exist (see Ang, 2008; Ritala, 2012), there could be various contingencies (moderating factors) affecting this link (Bengtsson et al., 2016; Hoffmann et al., 2018). Furthermore, as already noted, evidence also pertains to the potential for a linear and non-linear (inverted U-shaped) relationship between coopetition activities and company performance (following Bouncken and Kraus, 2013; Wu, 2014; Crick, 2018a). Henceforth, P1 and P2 depict the linear and non-linear linkages between coopetition and company performance. In addition, P3 and P4 highlight that the competitive business environment can have different moderating effects in the coopetition - company performance relationship (following Ang, 2008; Chiambaretto and Fernandez, 2016; Felzensztein et al., 2018). 
Further, P5 and P6 focus on how organizational resources and capabilities and trust between rivals respectively moderate the same link (building upon Lavie, 2006; Rusko, 2011; Kim et al., 2013; Bengtsson et al., 2016).

\section{Conceptual framework}

The coopetition - company performance relationship has been well-studied in the business-to-business marketing literature, with several authors arguing that by collaborating with competitors, managers can obtain new resources and capabilities that they would not have access to in an individualistic business model (Bengtsson and Kock, 1999; Ballantyne, 2004; Gnyawali and Park, 2011; Park et al., 2014; Ritala et al., 2014; Geldes et al., 2017). However, except for a few papers (see Ang, 2008; Ritala, 2012; Bouncken and Kraus, 2013; Wu, 2014; Chou and Zolkiewski, 2018), the relationship between coopetition activities and company performance has been evaluated (conceptually and empirically) as being non-contingent (Gnyawali and Park, 2009; Kim et al., 2013; Iyer, 2014; Peters and Pressey, 2016; Velu, 2016; Crick, 2018a). In this article, the relationship between coopetition activities and company performance was proposed to be linear and non-linear (inverted U-shaped) (P1 and P2). Additionally, three moderating factors were conceptualized, namely: the competitive business environment (P3 and P4), organizational resources and capabilities (P5), and trust between rivals (P6) (following Chiambaretto and Fernandez, 2016; Czakon and Czernek, 2016; Hoffmann et al., 2018) (Figure 1). By examining these contingencies, factors that help or hinder the performance outcomes of coopetition activities have been determined. Some managerial implications are highlighted in the following section.

[Insert Figure 1 about here] 


\section{Managerial implications}

In addition to its theoretical contribution, this paper also has several managerial implications. First, managers should engage in an "optimal-level" of coopetition, in which they share the correct amount of resources and capabilities with competing organizations. Managers should be aware that if they engage in "too little" coopetition, they might struggle to survive within their markets, due to not having a sufficient volume of resources and capabilities. Yet, "too much" coopetition can yield distrust between rival businesses (and lessen performance). Managers must strike an effective balance between not possessing enough resources and capabilities from their rivals (an individualistic business model), vis-à-vis, becoming too trusting of such organizations. Second, practitioners should be aware of how the competitive business environment can have different effects on company performance. Therefore, managers should constantly scan their markets for external forces (like competitive rivalry) that might indicate whether collaborating with their competitors is improving or reducing their performance.

This article conceptualized that the competitive business environment can have different effects on company performance, when coupled with coopetition activities. Hence, managers should appreciate whether their industry is more cooperative than competitive (or vice-versa) and engage in an appropriate degree of coopetition. Third, management teams should ensure that they are sharing the correct resources and capabilities with their competitors. That is, practitioners should attempt to access a large quantity of assets from rival firms, but also, strive to acquire the most effective resources and capabilities that they need to improve their performance. Fourth, managers should be cautious when they engage in coopetition activities, as there is a risk that they share their assets with untrustworthy competitors. Hence, managers 
should collaborate with rivals that they can trust (to avoid inter-firm tensions). Yet, it could be difficult to predict if competitors are trustworthy in advance of engaging in coopetition. Some limitations and avenues for future research are discussed as follows.

\section{Limitations and avenues for future research}

The study's limitations and avenues for future research are as follows. First, it is recommended that all three moderating factors (namely: the competitive business environment, organizational resources and capabilities, and trust between rivals) should feature across a series of future investigations. Specifically, authors should convert this study's research propositions into testable research hypotheses and evaluate them with quantitative data. Specifically, a survey-based methodology is recommended, as marketing scholars can collect such data through existing multiitem measures of the constructs within this paper's conceptual framework. For example, Bouncken and Kraus' (2013) measure of coopetition could be utilized, alongside Vorhies and Morgan's (2005) measure of company performance (under resource-based theory). Likewise, academics should also use a survey-based methodology to include multi-item operationalizations of the moderating variables within the conceptual framework, like the competitive business environment (following Jaworski and Kohli, 1993; Slater and Narver, 1994), as well as controlling the outcome variable for other factors that could explain its variance (e.g., firm size and firm age).

Using appropriate data analysis techniques, such as factor analyses and multiple regression (Combs and Ketchen Jr., 1999; O'Cass et al., 2015), marketing scholars should test each moderating factor across separate studies, whereby: one article examines the competitive business environment, another investigates organizational 
resources and capabilities, and another explores the trust between rivals. This way, clear evidence can emerge on the moderating role of certain constructs in the coopetition - company performance relationship. After checking for the different forms of reliability and validity (including common method variance) (following Bello et al., 2010), a survey-based methodology would develop this current study, with reasonable empirical (quantitative) data to test its assertions. Second, some markets are highlycooperative and highly-competitive, meaning that rich, coopetition-oriented findings can be obtained (Tuusjarvi and Moller, 2009; Bengtsson and Raza-Ullah, 2016; Mathias et al., 2018; Ranganathan et al., 2018). Other settings do not host highdegrees of cooperativeness and competitiveness (Kilduff et al., 2016; Crick, 2018b); thus, in future research, scholars should examine multiple industries (and countries) to better-understand how coopetition differs across empirical contexts.

Third, as coopetition activities can yield several company performance outcomes (Eriksson, 2008; lyer, 2014; Bengtsson et al., 2016; Crick, 2018a), the above-justified contingencies should be coupled with multiple performance outcomes to understand the extent to which these factors affect different dependent variables (see Ang, 2008; Ritala, 2012; Bouncken and Kraus, 2013; Wu, 2014). These assessments of company performance should be collaborative advantages (under the relational view) and sustainable competitive advantages (as per resource-based theory) (Gronroos, 1997; Dyer and Singh, 1998; Priem and Butler, 2001; Vorhies and Morgan, 2005; Butler and Batt, 2014; Dyer et al., 2018). As this paper is conceptual, it is even more important that future studies should test these assertions (using good measures and robust statistical procedures). For instance, following an earlier point, academics should use established measurement scales (where possible) to operationalize the: independent, 
moderating, and dependent variables. As already noted, a survey-based methodology would be appropriate to yield such directions for future research.

Fourth, the conceptualizations used in this paper were guided by the relational view and resource-based theory. While these perspectives were argued to be highlyrelevant, there are other marketing (and management) theories available to scholars. As some examples, contingency theory could be used to understand the role of the competitive business environment, whereas, agency theory could be applied to the trust-based moderator explored within this article. That said, although other theories are available to marketing academics, in this investigation, resource-based theory was supplemented by the relational view to conceptualize the quality of the relationships that companies have with their competitors (Combs and Ketchen Jr., 1999; Lavie, 2006; Coviello and Brodie, 2001; Mesquita et al., 2008; Ylimaki and Vesalainen, 2015), as well as the: linear, non-linear, and contingent effects on company performance (e.g., Ang, 2008; Ritala, 2012; Bouncken and Kraus, 2013; Crick, 2018a). Thus, marketing scholars should consider using alternative theoretical perspectives, but equally, should acknowledge that some theories do not apply to the coopetition literature. This study is concluded in the next section.

\section{Conclusions}

The objective of this paper was to examine the contingencies that could affect the relationship between coopetition and company performance. This objective was achieved through utilizing the relational view and resource-based theory to yield the following three conclusions. First, it is concluded that the coopetition - company performance relationship has been well-studied, but not many authors have examined the moderating factors affecting this link. Second, it is also concluded that: the 
competitive business environment, organizational resources and capabilities, and trust between rivals can moderate the relationship between coopetition activities and company performance. Third, it is lastly concluded that future research is needed to empirically-test the assertions made within this study. Should marketing scholars decide to pursue these directions for future research, there is ample scope to strengthen the coopetition literature. 


\section{References}

Akpinar, M. and Vincze, Z. (2016), "The dynamics of coopetition: a stakeholder view of the German automotive industry”, Industrial Marketing Management, Vol. 57 No. 1, pp. 53-63.

Ali, T. and Khalid, S. (2017), "Trust-performance relationship in international joint ventures: the moderating roles of structural mechanisms", Journal of Business \& Industrial Marketing, Vol. 32 No. 7, pp. 962-973.

Ang, S.H. (2008), "Competitive intensity and collaboration: impact on firm growth across technological environments", Strategic Management Journal, Vol. 29 No. 10, pp. 1057-1075.

Arslan, B. (2018), "The interplay of competitive and cooperative behavior and differential benefits in alliances", Strategic Management Journal, Vol. 39 No. 2, pp. 3222-3246.

Baker, M.J., Black, C.D. and Hart, S.J. (1988), "The competitiveness of British industry: what really makes the difference?", European Journal of Marketing, Vol. 22 No. 2, pp. $70-85$.

Ballantyne, D. (2004), "Dialogue and its role in the development of relationship-specific knowledge", Journal of Business \& Industrial Marketing, Vol. 19 No. 2, pp. 114123.

Barney, J.B. (1991), "Firm resources and sustained competitive advantage", Journal of Management, Vol. 17 No. 1, pp. 99-120.

Barney, J.B. (2001), "Is the resource-based view a useful perspective for strategic management research? Yes", Academy of Management Review, Vol. 26 No. 1, pp. 41-56.

Barney, J.B., Ketchen Jr., D.J. and Wright, M. (2011), "The future of resource-based theory: revitalization or decline?", Journal of Management, Vol. 37 No. 5, pp. 12991315.

Butler, B. and Batt, P.J. (2014), "Re-assessing value (co)-creation and cooperative advantage in international networks", Industrial Marketing Management, Vol. 43 No. 4 , pp. 538-542.

Bharadwaj, S.G., Varadarajan, P.R. and Fahy, J. (1993), "Sustainable competitive advantage in service industries: a conceptual model and research propositions", Journal of Marketing, Vol. 57 No. 4, pp. 83-99.

Bello, D.C., Katsikeas, C.S. and Robson, M.J. (2010), "Does accommodating a selfserving partner in an international marketing alliance pay off?", Journal of Marketing, Vol. 74 No. 6, pp. 77-93.

Bengtsson, M. and Johansson, M. (2014), "Managing coopetition to create opportunities for small firms", International Small Business Journal, Vol. 32 No. 4, pp. 401-427.

Bengtsson, M. and Kock, S. (1999), "Cooperation and competition in relationships between competitors in business networks", Journal of Business \& Industrial Marketing, Vol. 14 No. 3, pp. 178-194. 
Bengtsson, M. and Kock, S. (2000), "Coopetition in business networks: to cooperate and compete simultaneously", Industrial Marketing Management, Vol. 29 No. 5, pp. 411-426.

Bengtsson, M. and Kock, S. (2014), "Coopetition-quo vadis? Past accomplishments and future challenges", Industrial Marketing Management, Vol. 43 No. 2, pp. 180188.

Bengtsson, M. and Raza-Ullah, T. (2016), "A systematic review of research on coopetition: toward a multi-level understanding", Industrial Marketing Management, Vol. 57 No. 1, pp. 23-39.

Bengtsson, M., Kock, S., Lundgren-Henriksson, E-L. and Nasholm, M.H. (2016), "Coopetition research in theory and practice: growing new theoretical, empirical, and methodological domains", Industrial Marketing Management, Vol. 57 No. 1, pp. 4-11.

Bouncken, R.B. and Kraus, S. (2013), "Innovation in knowledge-intensive industries: the double-edged sword of coopetition", Journal of Business Research, Vol. 66 No. 10 , pp. 2060-2070.

Brandenburger, A.M. and Nalebuff, B.J. (1996), Co-opetition, Doubleday Dell Publishing Group Inc., New York: NY.

Carbonell, P. and Escudero, A.I. (2010), "The effect of market orientation on innovation speed and new product performance", Journal of Business \& Industrial Marketing, Vol. 25 No. 7, pp. 501-513.

Chiambaretto, P. and Fernandez, A.S. (2016), "The evolution of coopetitive and collaborative alliances in an alliance portfolio: the Air France case", Industrial Marketing Management, Vol. 57 No. 1, pp. 75-85.

Chou, H.H. and Zolkiewski, J. (2018), "Coopetition and value creation and appropriation: the role of interdependencies, tensions and harmony", Industrial Marketing Management, Vol. 70 No. 1, pp. 25-33.

Combs, J.G. and Ketchen Jr., D.J. (1999), "Explaining inter-firm cooperation and performance: toward a reconciliation of predictions from the resource-based view and organizational economics", Strategic Management Journal, Vol. 20 No. 9, pp. 867-888.

Coviello, N.E. and Brodie, R.J. (2001), "Contemporary marketing practices of consumer and business-to-business firms: how different are they?", Journal of Business \& Industrial Marketing, Vol. 16 No. 5, pp. 382-400.

Crick, D. and Crick, J.M. (2014), "The internationalization strategies of rapidly internationalizing high-tech UK SMEs: planned and unplanned activities", European Business Review, Vol. 26 No. 5, pp. 421-448.

Crick, D. and Crick, J.M. (2015), "Learning and decision-making in marketing planning: a study of New Zealand vineyards", Marketing Intelligence \& Planning, Vol. 33 No. 5, pp. 707-732.

Crick, D. and Crick, J.M. (2016), "Coopetition at the sports marketing/entrepreneurship interface: a case study of a Taekwondo organisation”, Marketing Intelligence \& Planning, Vol. 34 No. 2, pp. 169-187. 
Crick, D., Chaudhry, S. and Crick, J.M. (2016), "Trading in a competitive environment: South-Asian restaurants in the UK”, Strategic Change, Vol. 25 No. 4, pp. 169-187.

Crick, J.M. (2015), "Bridging the gap between threshold and dynamic capabilities: a qualitative study of the collaboration strategies of New Zealand wineries", unpublished Master of Business Studies thesis in management, Massey University, New Zealand.

Crick, J.M. (2018a), "The facets, antecedents and consequences of coopetition: an entrepreneurial marketing perspective", Qualitative Market Research: An International Journal, Vol. 21 No. 2, pp. 253-272.

Crick, J.M. (2018b), "Studying coopetition in a wine industry context: directions for future research", International Journal of Wine Business Research, Vol. 30 No. 3, pp. 366-371.

Crick, J.M. and Crick, D. (2018), “Angel investors' predictive and control funding criteria: the importance of evolving business models", Journal of Research in Marketing and Entrepreneurship, Vol. 20 No. 1, pp. 34-56.

Czakon, W. and Czernek, K. (2016), "The role of trust-building mechanisms in entering into network coopetition: the case of tourism networks in Poland", Industrial Marketing Management, Vol. 57 No. 1, pp. 64-74.

Dahl, J. (2014), "Conceptualizing coopetition as a process: an outline of change in cooperative and competitive interactions", Industrial Marketing Management, Vol. 43 No. 2, pp. 272-279.

Dowling, M.J., Roering, W.D., Carlin, B.A. and Wisnieski, J. (1996), "Multi-faceted relationships under coopetition: description and theory", Journal of Management Inquiry, Vol. 5 No. 2, pp. 155-167.

Dyer, J.H. and Singh, H. (1998), "The relational view: cooperative strategy and sources of inter-organizational competitive advantage", Academy of Management Review, Vol. 23 No. 4, pp. 660-679.

Dyer, J.H., Singh, H. and Hesterly, W.S. (2018), "The relational view revisited: a dynamic perspective on value creation and value capture", Strategic Management Journal, Vol. 39 No. 12, pp. 3140-3162.

Eriksson, P.E. (2008), "Achieving suitable coopetition in buyer-supplier relationships: the case of AstraZeneca", Journal of Business-to-Business Marketing, Vol. 15 No. 4, pp. 425-454.

Felzensztein, C., Gimmon E. and Aqueveque, C. (2012), "Clusters or un-clustered industries? Where inter-firm marketing cooperation matters", Journal of Business \& Industrial Marketing, Vol. 27 No. 5, pp. 392-402.

Felzensztein, C., Gimmon, E. and Deans, K.R. (2018), "Coopetition in regional clusters: keep calm and expect unexpected changes", Industrial Marketing Management, Vol. 69 No. 1, pp. 116-124.

Fernandez, A.S. and Chiambaretto, P. (2016), "Managing tensions related to information in coopetition", Industrial Marketing Management, Vol. 53 No. 1, pp. 66-76. 
Ganesan, S., Malter, A.J. and Rindfleisch, A. (2005), "Does distance still matter? Geographic proximity and new product development", Journal of Marketing, Vol. 69 No. 4, pp. 44-60.

Geldes, C., Heredia, J., Felzensztein, C. and Mora, M. (2017), "Proximity as determinant of business cooperation for technological and non-technological innovations: a study of an agribusiness cluster", Journal of Business \& Industrial Marketing, Vol. 32 No. 1, pp. 167-178.

Girod, S.J.G. and Whittington, R. (2017), "Reconfiguration, restructuring and firm performance: dynamic capabilities and environmental dynamism", Strategic Management Journal, Vol. 38 No. 5, pp. 1121-1133.

Glynn, M.S., Motion, J. and Brodie, R.J. (2007), "Sources of brand benefits in manufacturer-reseller B2B relationships", Journal of Business \& Industrial Marketing, Vol. 22 No. 6, pp. 400-409.

Gnyawali, D.R. and Charleton, T.R. (2018), "Nuances in the interplay of competition and cooperation: towards a theory of coopetition", Journal of Management, Vol. 44 No. 7, pp. 2511-2534.

Gnyawali, D.R. and Park, B.J.R. (2009), "Coopetition and technological innovation in small and medium-sized enterprises: a multi-level conceptual model", Journal of Small Business Management, Vol. 47 No. 3, pp. 308-330.

Gnyawali D.R. and Park, B.J.R. (2011), "Coopetition between giants: collaboration with competitors for technological innovation", Research Policy, Vol. 40 No. 5, pp. 650-663.

Granata, J., Lasch, F., Le Roy, F. and Dana, L-P. (2018), "How do micro-firms manage coopetition? A study of the wine sector in France", International Small Business Journal, Vol. 36 No. 3, pp. 331-355.

Gronroos, C. (1997), "Value-driven relational marketing: from products to resources and competencies", Journal of Marketing Management, Vol. 13 No. 5, pp. 407419.

Hannah, D.P. and Eisenhardt, K.M. (2018), "How firms navigate cooperation and competition in nascent ecosystems", Strategic Management Journal, Vol. 39 No. 12, pp. 3163-3192.

Hoffmann, W., Lavie, D., Reuer, J.J. and Shiplov, A. (2018), "The interplay of competition and cooperation", Strategic Management Journal, Vol. 39 No. 12, pp. 3033-3052.

Hoskisson, R.E., Gambeta, E., Green, C.D. and Li, T.X. (2018), "Is my firm-specific investment protected? Overcoming the stakeholder investment dilemma in the resource-based view", Academy of Management Review, Vol. 43 No. 2, pp. 284306.

Hunt, S.D. and Derozier, C. (2004), "The normative imperatives of business and marketing strategy: grounding strategy in resource-advantage theory", Journal of Business \& Industrial Marketing, Vol. 19 No. 1, pp. 5-22.

Hunt, S.D. and Morgan, R.M. (1995), "The comparative advantage theory of competition”, Journal of Marketing, Vol. 59 No. 2, pp. 1-15. 
Iyer, K.N.S. (2014), "Operational impact of collaboration and resource specificity: the moderating role of technology context", Journal of Business \& Industrial Marketing, Vol. 29 No. 5, pp. 387-399.

Jaworski, B.J. and Kohli, A.K. (1993), "Market orientation: antecedents and consequences", Journal of Marketing, Vol. 57 No. 3, pp. 53-70.

Kanter, R.M. (1994), "Collaborative advantage: the art of alliances", Harvard Business Review, Vol. 72 No. 4, pp. 96-108.

Katsikeas, C.S., Morgan, N.A., Leonidou, L.C. and Hult, G.T.M. (2016), "Assessing performance outcomes in marketing", Journal of Marketing, Vol. 80 No. 2, pp. 120.

Khalid, T. and Ali, S. (2017), "Trust-performance relationship in international joint ventures: the moderating roles of structural mechanisms", Journal of Business \& Industrial Marketing, Vol. 32 No. 7, pp. 962-973.

Kilduff, G.J., Galinsky, A.D., Gallo, E. and Reade, J.J. (2016), "Whatever it takes to win: rivalry increases unethical behavior", Academy of Management Journal, Vol. 59 No. 5 , pp. 1508-1534.

Kim, S., Kim, N., Pae, J.H. and Yip, L. (2013), "Cooperate and compete: coopetition strategy in retailer-supplier relationships", Journal of Business \& Industrial Marketing, Vol. 28 No. 4, pp. 263-275.

Kumar, V. (2010), "Transformative marketing: the next 20 years", Journal of Marketing, Vol. 82 No. 4, pp. 1-12.

Kumar, V., Jones, E., Venkatesan, R. and Leone, R.P. (2011), "Is market orientation a source of sustainable competitive advantage or simply the cost of competing?", Journal of Marketing, Vol. 75 No. 1, pp. 16-30.

Kunc, M.H. and Morecroft, J.D.W. (2010), "Managerial decision-making and firm performance under a resource-based paradigm", Strategic Management Journal, Vol. 31 No. 11, pp. 1164-1182.

Lavie, D. (2006), "The competitive advantage of inter-connected firms: an extension of the resource-based view", Academy of Management Review, Vol. 31 No. 3, pp. 638-658.

Leite, E., Pahlberg, C. and Aberg, S. (2018), "The cooperation-competition interplay in the ICT industry", Journal of Business \& Industrial Marketing, Vol. 33 No. 4, pp. 495-505.

Luo, X., Slotegraaf, R.J. and Pan, X. (2006), "Cross-functional coopetition: the simultaneous role of cooperation and competition within firms", Journal of Marketing, Vol. 70 No. 2, pp. 67-80.

Luo, Y. (2005), "Toward coopetition within a multinational enterprise: a perspective from foreign subsidiaries", Journal of World Business, Vol. 40 No. 1, pp. 71-90.

Luo, Y. (2007), "A coopetition perspective of global competition", Journal of World Business, Vol. 42 No. 2, pp. 129-144. 
Mathias, B.D., Huyghe, A., Frid, C.J. and Galloway, T.L. (2018), "An identity perspective on coopetition in the craft beer industry", Strategic Management Journal, Vol. 39 No. 12, pp. 3086-3115.

Mesquita, L.F., Anand, J. and Brush, T.H. (2008), "Comparing the resource-based and relational views: knowledge transfer and spill-over in vertical alliances", Strategic Management Journal, Vol. 29 No. 9, pp. 913-941.

Morgan, N.A. (2012), "Marketing and business performance", Journal of the Academy of Marketing Science, Vol. 40 No. 1, pp. 102-119.

Morgan, R.E., Strong, C.A. and McGuiness, T. (2003), "Product-market positioning and prospector strategy: an analysis of strategic patterns from the resource-based perspective", European Journal of Marketing, Vol. 37 No. 10, pp. 1409-1439.

Nason, R.S. and Wiklund, J. (2018), "An assessment of resource-based theorizing on firm growth and suggestions for the future", Journal of Management, Vol. 44 No. 1, pp. 32-60.

Newbert, S.L. (2007), "Empirical research on the resource-based view of the firm: an assessment and suggestions for future research", Strategic Management Journal, Vol. 28 No. 2, pp. 121-146.

O'Cass, A., Ngo, L.V. and Siahtiri, V. (2015), "Marketing resource-capability complementarity and firm performance in B2B firms", Journal of Business \& Industrial Marketing, Vol. 30 No. 2, pp. 194-207.

Olson, E.M., Slater, S.F., Hult, G.T.M. and Olson, K.M. (2018), "The application of human resource management policies within the marketing organization: the impact on business and marketing strategy implementation", Industrial Marketing Management, Vol. 69 No. 1, pp. 62-73.

Ozkaya, H.E., Droge, C., Hult, G.T.M., Calantone, R. and Ozkaya, E. (2015), "Market orientation, knowledge competence, and innovation", International Journal of Research in Marketing, Vol. 32 No. 3, pp. 309-318.

Park, B.J.R., Srivastava, M.K. and Gnyawali, D.R. (2014), "Walking the tightrope of coopetition: impact of competition and cooperation intensities and balance on firm innovation performance", Industrial Marketing Management, Vol. 43 No. 2, pp. 210-221.

Peters, L.D. and Pressey, A.D. (2016), "The coordinative practices of temporary organisations", Journal of Business \& Industrial Marketing, Vol. 31 No. 2, pp. $301-$ 311.

Piercy, N.F. (2010), "Evolution of strategic sales organizations in business-to-business marketing", Journal of Business \& Industrial Marketing, Vol. 25 No. 5, pp. 349-359.

Ploetner, O. and Ehret, M. (2006), "From relationships to partnerships: new forms of cooperation between buyer and seller", Industrial Marketing Management, Vol. 35 No. 1, pp. 4-9.

Porter, M.E. (1985), Competitive Advantage: Creating and Sustaining Superior Performance, Free Press, New York: NY. 
Priem, R.L. and Butler, J.E. (2001), "Is the resource-based view a useful perspective for strategic management research?", Academy of Management Review, Vol. 26 No. 1, pp. 22-40.

Ranganathan, R., Ghosh, A. and Rosenkopf, L. (2018), "Competition-cooperation interplay during multi-firm technology coordination: the effect of firm heterogeneity on conflict and consensus in a technology standards organization", Strategic Management Journal, Vol. 39 No. 12, pp. 3193-3221.

Rao, S. and Perry, C. (2002), "Thinking about relationship marketing: where are we now?", Journal of Business \& Industrial Marketing, Vol. 17 No. 7, pp. 598-614.

Raza-Ullah, T., Bengtsson, M. and Kock, S. (2014), "The coopetition paradox and tension in coopetition at multiple-levels", Industrial Marketing Management, Vol. 43 No. 2, pp. 189-198.

Ritala, P. (2012), "Coopetition strategy - when is it successful? Empirical evidence on innovation and market performance", British Journal of Management, Vol. 23 No. 3, pp. 307-324.

Ritala, P. and Hurmelinna-Laukkanen, P. (2013), "Incremental and radical innovation in coopetition: the role of absorptive capacity and appropriability", Journal of Product Innovation Management, Vol. 30 No. 1, pp. 154-169.

Ritala, P., Golnam, A. and Wegmann, A. (2014), "Coopetition-based business models: the case of Amazon.com", Industrial Marketing Management, Vol. 43 No. 2, pp. 236-249.

Rosenfeld, S.A. (1996), "Does cooperation enhance competitiveness? Assessing the impacts of inter-firm collaboration", Research Policy, Vol. 25 No. 2, pp. 247-263.

Rusko, R. (2011), "Exploring the concept of coopetition: a typology for the strategic moves of the Finnish forest industry", Industrial Marketing Management, Vol. 40 No. 2, pp. 311-320.

Slater, S.F. and Narver, J.C. (1994), "Does competitive environment moderate the market orientation-performance relationship?", Journal of Marketing, Vol. 58 No. 1, pp. 46-55.

Teece, D.J. (2018), "Business models and dynamic capabilities", Long Range Planning, Vol. 51 No. 1, pp. 40-49.

Teece, D.J., Pisano, G. and Shuen, A. (1997), "Dynamic capabilities and strategic management", Strategic Management Journal, Vol. 18 No. 7, pp. 509-533.

Tidstrom, A. (2009), "Causes of conflict in inter-competitor cooperation", Journal of Business \& Industrial Marketing, Vol. 24 No. 7, pp. 506-518.

Tidstrom, A. (2014), "Managing tensions in coopetition", Industrial Marketing Management, Vol. 43 No. 2, pp. 261-271.

Tuusjarvi, E. and Moller, K. (2009), "Multiplicity of norms in inter-company cooperation", Journal of Business \& Industrial Marketing, Vol. 24 No. 7, pp. 519528. 
Tzempelikos, N. and Kooli, K. (2018), "Moderating effects of environmental uncertainty on behavioural intentions in business markets: a study across theoretical perspectives", Journal of Business \& Industrial Marketing, Vol. 33 No. 7, pp. 10371051.

Tzokas, N. and Saren, M. (2004), "Competitive advantage, knowledge and relationship marketing: where, what and how?”, Journal of Business \& Industrial Marketing, Vol. 19 No. 2, pp. 124-135.

Velu, C. (2016), "Evolutionary or revolutionary business model innovation through coopetition? The role of dominance in network markets", Industrial Marketing Management, Vol. 53 No. 1, pp. 124-135.

Vorhies, D.W. and Morgan, N.A. (2005), "Benchmarking marketing capabilities for sustainable competitive advantage", Journal of Marketing, Vol. 69 No. 1, pp. 8094.

Wernerfelt, B. (1984), "A resource-based view of the firm", Strategic Management Journal, Vol. 5 No. 2, pp. 171-180.

Wernerfelt, B. (2014), "On the role of the RBV in marketing", Journal of the Academy of Marketing Science, Vol. 42 No. 1, pp. 22-23.

Westhead, P., Wright, M. and Ucbasaran, D. (2001), "The internationalization of new and small firms: a resource-based view", Journal of Business Venturing, Vol. 16 No. 4, pp. 333-358.

Winter, S.G. (2003), "Understanding dynamic capabilities", Strategic Management Journal, Vol. 24 No. 10, pp. 991-995.

Wu, J. (2014), "Cooperation with competitors and product innovation: moderating effects of technological capability and alliances with universities", Industrial Marketing Management, Vol. 43 No. 2, pp. 199-209.

Xie, F.T. and Johnston, W.J. (2004), "Strategic alliances: incorporating the impact of e-business technological innovations", Journal of Business \& Industrial Marketing, Vol. 19 No. 3, pp. 208-222.

Yami, S. and Nemeh, A. (2014), "Organizing coopetition for innovation: the case of wireless telecommunication sector in Europe", Industrial Marketing Management, Vol. 43 No. 2, pp. 250-260.

Ylimaki, J. and Vesalainen, J. (2015), "Relational development of a service concept: dialogue meets efficiency", Journal of Business \& Industrial Marketing, Vol. 30 No. 8, pp. 939-950.

Zahra, S.A., Sapienza, H.J. and Davidsson, P. (2006), "Entrepreneurship and dynamic capabilities: a review, model and research agenda", Journal of Management Studies, Vol. 43 No. 4, pp. 917-955. 
Figure 1. Conceptual framework

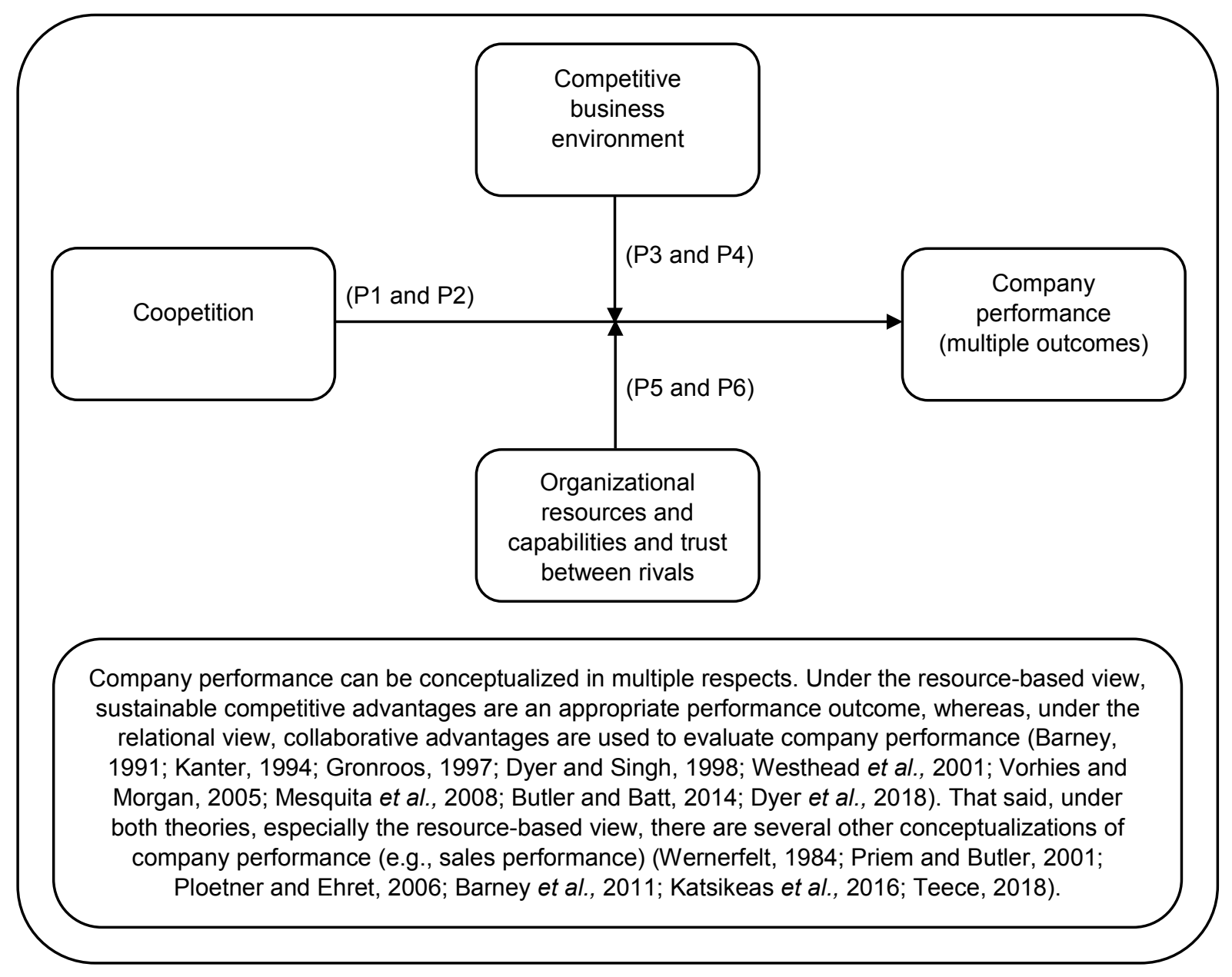

